\title{
TheTextual Condition
}


$\begin{array}{lllllll}\text { E } & \mathbf{D} & \mathbf{I} & \mathbf{T} & \mathbf{O} & \mathbf{R} & \mathbf{S}\end{array}$

Sherry B. Ortner, Nicholas B. Dirks, Geoff Eley

A list of titles in this series appears at the back of the book 

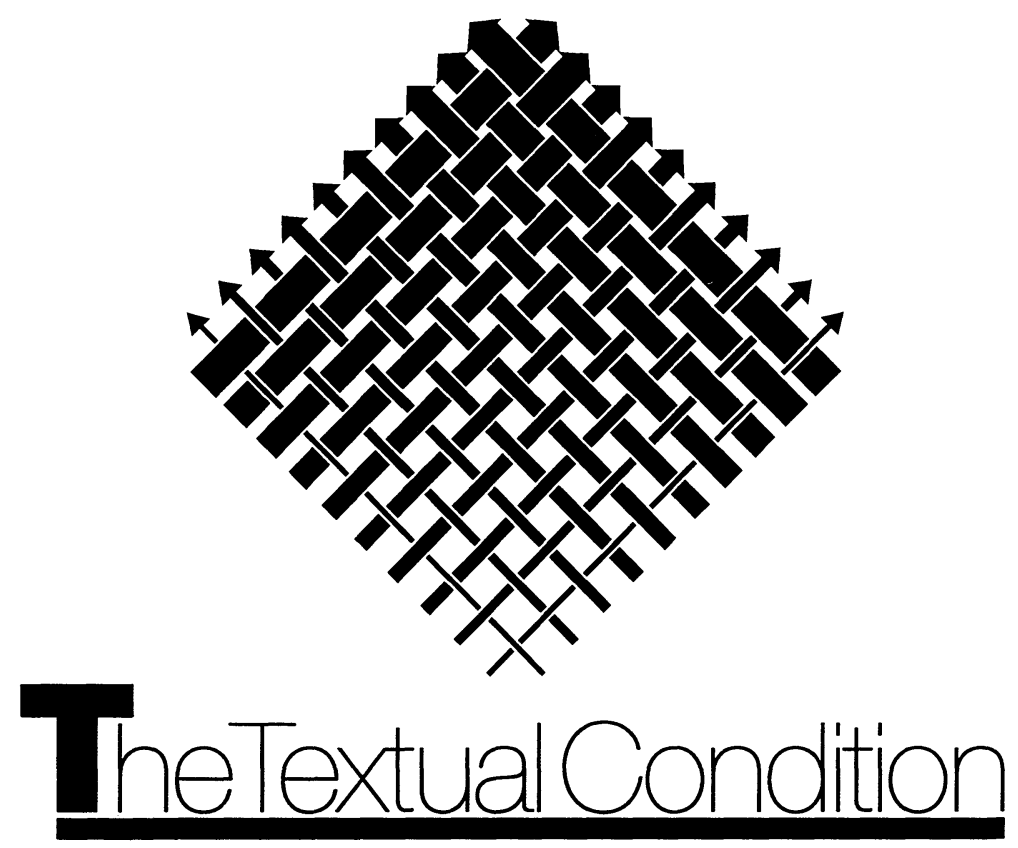

\section{JEROME J. M C GAN N}


Copyright (C) 1991 by Princeton University Press Published by Princeton University Press, 41 William Street, Princeton, New Jersey 08540

In the United Kingdom: Princeton University Press, Chichester, West Sussex

All Rights Reserved

Library of Congress Cataloging-in-Publication Data

McGann, Jerome J.

The textual condition / Jerome J. McGann

p. $\mathrm{cm} .-$ (Princeton studies in culture/power/history)

Includes bibliographical references and index.

ISBN 0-691-06931-X - 0-691-01518-X (pbk.)

1. English literature-Criticism, Textual. 2. American

literature-Criticism, Textual. 3. English literature-History and

criticism-Theory, etc. 4. American literature-History and criticism-Theory, etc. 5. Pound, Ezra, 1885-1972-Criticism,

Textual. 6. Transmission of texts. 7. Criticism, Textual. 8. Editing. I. Title. II. Series. PR21.M37 1991

801'.959—dc20 91-16996 CIP

This book has been composed in Linotron Sabon and Helvetica

Princeton University Press books are printed on acid-free paper and meet the guidelines for permanence and durability of the Committee on Production Guidelines for Book Longevity of the Council on Library Resources

Printed in the United States of America by Princeton Academic Press

$$
\begin{array}{lllllllll}
3 & 5 & 7 & 9 & 10 & 8 & 6 & 4 & 2
\end{array}
$$

Excerpts from the following were reprinted by permission:

Ezra Pound: The Cantos of Ezra Pound. Copyright (C) 1934, 1948, 1962, 1968

by Ezra Pound. Reprinted by permission of New Directions

Publishing Corporation. 


\section{FOR VIRGIL}

The eyes of fire, the nostrils of air, the mouth of water, the beard of earth. 



\section{You can't have art without \\ resistance in the material.}

—William Morris

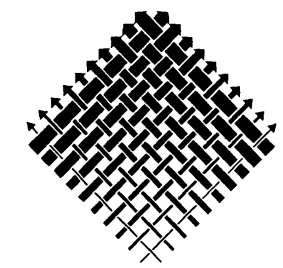


